\title{
Analyzing students' speech construction through their recorded videos
}

\author{
Ingrid Jhoana Nomesque Morales ${ }^{1}$ \\ Nomesque M,Ingrid $\mathbf{J}$ \\ miradas $\mathrm{N}^{\circ} 14$ - 2016. ISSN: 0122 994X Págs 93 - 112 \\ Recepción: Junio 18 de 2016 \\ Aprobación: Octubre 03 de 2016 \\ Publicación: Diciembre 20 de 2016
}

\section{Description}

Report of the research and pedagogical process developed in foreign language's teaching with the Intermediate level conversational group of the Language Center. This project is focus on the observation, description and implementation of different activities in order to analyze all communicative strategies used by students to construct their own oral English performance, taking as a start-point the development of short video emissions based on four different kinds of speeches in English.

Moreover, the data collecting techniques also make part of the pedagogical design, because the video recordings and field notes show how students construct their own speech using their previous knowledge to talk and interact in English with their own realities.

\section{Sources}

This document is based on four main points: communication, communicative approach, analysis performance and media resources. In this way, it is necessary to consult several texts including articles, books, thesis and virtual sources, which give a theoretical support according to the type of information the proposal is concentrated on. Thus, it is pertinent to name some authors like Birdwhistell, Briones, Davis, Erlbawn, Littlewood and Pastor, whose theoretical bases support the development of this project.

\section{Contents}

This document presents an introduction where it is described the development of this project; a justification where it is explained the reasons and the causes of the investigation, after that, it comes the research question and the objectives which are the beginning of the proposal. Next, the literature review is composed by theoretical bases divided into four spheres. Then, the research design develops the type of study, stages, setting, population

1 Licenciada en Humanidades y Lenguas Extranjeras de la Universidad Pedagogica Nacional en 2011. Especialista en Comunicación Educativa de la Corporación Universitaria Minuto de Dios. inomesque@gmail.com 
and data collecting techniques. Afterwards, it comes the pedagogical design, where it is described the project's development, activities and their stages as well. Finally, the data analysis, conclusions, implications and annexes are presented as support of the long process developed in this proposal.

\section{Methodology}

This project is based on a descriptive study of the intermediate students' oral performance of the Language Center, where the observation, description and analysis of all communicative strategies used by them facilitate the analysis of their oral skill concentrated on how they construct their own speeches.

In this way, this project uses the same collecting data techniques as part of the implementation activities towards the analysis of the students' oral performance and communicative strategies used in the construction of their own way to speak in English.

\section{Conclusions}

The research process showed that students take always into account their previous knowledge and specific interests to construct their own speeches, which give them confidence to start speaking in English. At the same time, the familiar environment created by the teacher allows an active participation in class, where we can appreciated and analyze their oral skill performance improvement.

Key Words: Communication, communicative approach, oral, performance, speech analysis and video use.

Palabras Clave: Comunicación, enfoque comunicativo, habilidad oral, análisis de discursos en inglés y el uso del video.

\section{Descripción}

Informe de investigación y proceso pedagógico desarrollado con estudiantes del grupo conversacional de nivel intermedio del Centro de lenguas en la enseñanza de una lengua extranjera. Este proyecto está enfocado en la observación, descripción e implementación de diferentes actividades para analizar todas las estrategias comunicativas usadas por los estudiantes para construir sus propias presentaciones orales en Ingles, tomando como punto de partida el desarrollo de pequeños videos basados en cuatro clases de discursos en inglés.

Además, las técnicas de recolección de datos hacen también parte del diseño pedagógico, ya que la grabación de videos y los diarios de campo muestran como los estudiantes construyen sus propios discursos hacienda uso de sus conocimientos previos para hablar e interactuar en ingles con sus propias realidades.

\section{Fuentes}

Este documento está basado en cuatro puntos principales: comunicación, enfoque comunicativo, análisis de discurso y recursos audiovisuales. De esta manera, fue necesario consultar varios textos incluyendo artículos, libros, tesis and recursos virtuales, los cuales fijan las bases teóricas del proyecto de acuerdo al tipo de información manejada en esta propuesta. Debido a esto, es pertinente nombrar algunos autores como Birdwhistell, Briones, Davis, Erlbawn, Littlewood y Pastor, quienes conforman el marco de referencia en el desarrollo de este proyecto.

\section{Contenidos}

Este documento presenta una introducción donde se describe el desarrollo del proyecto, una justificación donde se explican las razones las causas de la 
investigación, después se encuentra la pregunta de investigación y los objetivos, en los que se fundamenta la propuesta. El marco conceptual está compuesto por las bases teóricas divididas en cuatro esferas. Luego, el diseño investigativo desarrolla el tipo de estudio, etapas, contexto, población y técnicas de recolección de datos. Más tarde, viene el diseño pedagógico donde se describe el desarrollo del proyecto, actividades y sus etapas también. Finalmente, el análisis de datos, las conclusiones, implicaciones y anexos son presentados como soporte del largo proceso desarrollado en esta propuesta.

\section{Metodología}

Este proyecto esta basado en un estudio descriptivo de la presentación oral de los estudiantes de nivel intermedio del Centro de Lenguas, donde la observación, descripción y análisis de todas las estrategias comunicativas usadas por ellos, las cuales facilitan el análisis de su habilidad oral concentrada en como ellos construyen sus propios discursos. De esta manera, este proyecto usa las mismas técnicas de recolección de datos como parte de las actividades de implementación hacia el análisis de la actividad oral de los estudiantes y las estrategias comunicativas.

\section{Conclusiones}

El proceso investigativo mostro que los estudiantes toman siempre en cuenta sus conocimientos previos e intereses específicos para construir sus propios discursos, los cuales le brindan seguridad al hablar en Ingles. De la misma manera, el ambiente familiar creado por el docente permite una participación activa por parte de los estudiantes en clase, donde podemos apreciar y analizar sus avances realizados en sus presentaciones orales.

\section{Abstract}

This project is address to all those language teachers interested in the oral speech construction through video performance analysis using the video as a didactic tool in the learning process and as an evidence of the students' oral production. Thus, this project divided this study into five main parts.

The first one deals with the introduction, justification, problem statement and objectives of this proposal. The second part, works on the literature review and different theories and approaches that support this research. The third one makes reference to the research design, type of study, structure and data collecting techniques. The fourth part includes the pedagogical design composed by the activities as well as its development stages. The data analysis, conclusions and implications come last, where all information is organized, analyzed and supported with the annexes, which are an extension from the material presented along all project.

\section{Introduction}

The present project has emerged from my pedagogical practice in the Language Centre and has been developed with intermediate level students, who make part of the conversational course. During the research process I observed that they realize the importance of English in their lives and they are really motivated and interested in the development of the course, because they have already seen previous English levels based on grammar and functions, and they have expressed their need to improve and practice their oral skill.

In addition to that, if we see the oral skill place in the Colombian educative process, there is a lack of consideration of this skill into the English learning classes, because first of all this ability is uncommon live 
out, the topics are not interesting and sometimes the activities to practice this skill are too limited, which motivates me to find other strategies to get the students close to the improvement of this ability.

Thus, there is no doubt that the idea of studying speaking skill and all the communicative strategies used by students is useful and helpful not only for the English language learning but also, because this study involves the communication and social interaction in different ways.

Therefore, this proposal is focus on how students build their own English speech through the use of different discourses, and it is based on the descriptive research and its components, which is going to facilitate the analysis of students' oral performance through the video recording and data analysis taken from all the communicative gears seen in each performance.

Indeed, I consider every communicative act is full of meanings where students show how they talk and express their thought in a foreign language. In this way, I will take into account all the communicative patterns they use while they are talking in English.

According to this, this project works on a critical description about all the strategies used by the students when they talk, and work on four main concepts: communication (verbal and non-verbal), performance analysis, communicative approach and media use, because these topics provide accurate theoretical information to develop this research.

In short, it is important to say this project and all its pedagogical design will promote a real communicative language production and will help the students to improve their speaking skill through different oral activities based on the reproduction of four different types of speeches, each one of them with a communicative objective and a specific way to present it.

\section{Justification}

This proposal has been developed to analyze all communicative strategies used in the oral performance of some of the intermediate level students. Looking for a way to overcome this situation, I consider the analysis of different English speeches made by the students and recorded on video, can be a good way to study the oral performance and its communicative role.

For instance, this project takes into account four different kinds of speeches, each one of them with a specific organization and way to do it, where students have to use their oral ability to manage information and being effective to share it, at the same time they practice and improve their pronunciation and increase their selfconfidence to talk.

In this way, this project is relevant for the institution, first of all due to the fact that it provides a useful tool for registering, keeping and processing the language English performance of some of the Language Center students; second, for seeing the students' communicative progress through the video recording, where we can see their improvements in the Conversational course since their first oral presentation to the last one; and finally, because the pedagogical design will support the conversational group final project, where the students will show their English level to the other courses from the

Language Center through an oral final presentation based on different kinds of speeches.

Finally, I hope this project could be meaningful for teachers and researches that might be interested in use this paper or some of its statements to get a general knowledge about the English oral performance and communicative strategies, and could create new alternatives to improve the students' oral skill. 


\section{Problem Statement}

During the research process, the intermediate students from the Language Center showed a receptive attitude towards all conversational activities made in class, and through most of the oral interactions, I have seen they can handle long conversations and give their point of view in a critical way, what makes me be aware of the importance of proposing and promoting activities in which learners can play an active role and can communicate their opinions and ideas by linking their own realities.

On the other hand, they have expressed their desire for improving their pronunciation and intonation to talk in a natural way, and have expressed the importance of English learning in their lives, because of their job and studies opportunities, which means there is no doubt the students are concerned about their speaking process looking forward their future plans.

At the same time, the conversational course gives to the students an important and meaningful communicative space, where teacher can motivate them through different communicative activities to improve their speaking level and get high their self-confidence by the desire of exchange information in different ways.

Thus, the current project has as a main objective the analysis of students' speech construction taking into account their oral performance and communicative strategies by sharing information through different kinds of speeches. In this way they will practice their speaking skill and oral presentations in front of their own classmates and later to the students' community in the final project, while I analyze their performance and how they construct their own ideas to talk in public characterizing all the communicative roles used to interact in English.

\section{Literature Review}

During years, the English grammar studies had been the central point in the language learning, but nowadays these studies based on the different learning and teaching approaches have been developed through the four communicative skills. As well, the social linguistic factors and different migration process have increased the languages studies focus on the way to teach and the way to learn.

Thus, this project will work on the analysis of the student's oral performance construction through the description of their oral ability and all strategies used by them to communicate what they want to say in an oral way, but before start talking about the research made in this field, it is necessary to explain that the theoretical bases of this project are focus on: verbal and non verbal communication, communicative approach, analysis performance and use of videos as a technological resource.

\section{Verbal and Non-verbal Communication}

According to Ray Birdwhistell, the communication is "a negotiation between two people involved in a creative act where the emotions and other feelings are expressed from different ways". At the same time, he says the communication is not only the verbal part, because as the sentences have meanings, the corporal movements also have meaningful effects.

Taking into account the oral language is one of the communicative ways more used by the human being, it is important appreciate the elements that enriched the oral communication, like gestures, kind of vocabulary, voice articulation, and audio-visual aids, all of these resources provide a better communication among the interlocutors. 
Thus, the gestures started to be analyzed at the beginning of the 40 decade with David Efron, who wrote "Gesture and environments", and who said the way to speak always go with the way of gesticulate.

As Sapir wrote "people answer to the gestures with a special viveza, according to a code which is not written anywhere, which nobody knows, but everybody understands", that's why we cannot study the communication in separate ways, because it is an integral system that has to relate each communicative element to the interaction between two or more people.

On the other hand, as the language is the ability that separates the human being from the animals, some scientific have affirmed that the oral communication wouldn't be possible without the non-verbal elements, elements that come from the culture and make part of variables more meaningful than the verbal content, because through the oral interaction we can see the changes in the pronunciation, the messages, the non-verbal behavior, and other variables that characterize a specific social group.

At the same time, the communication has different communicative objectives such as get a job, chat a little bit, ask for information and give a lesson, but it has different kind of people (friends, teacher, and colleagues), and situations (at home, at the office, at the park), where the oral communication plays a specific role to understand message and communicate ideas.

Because of this, it is important to get the comprehension of all communicative elements, and provide the reader useful tools that facilitate him establish a good oral communication. In this way, I am going to describe the most relevant characteristics of some body parts that help to develop the communication, because all other gestures made by the people with any of their body parts are not fortuitous.
For example, the eyes determine what people see, and the studies about the nonverbal communication have demonstrated that the eyes movements also regulate the conversations (Davis, 1986: 89), an example of this could be when the eyes movements work as a signal system that indicate the interlocutor's turn to speak.

The hands are gestures that illustrate our words. Most of the people have conscience about the hands movements of other people, but they do not have it in themselves, it means they ignore that the movements of the hands contribute to understand better a message that was not clear.

In this sense, the hands squeezed stronger or when both hands play one with the other is a symptom of tension. Also, when people use its hands to draw figures in the air, they made this to underline or show what they say.

Edwar Hall, an anthropology teacher, was the first one in study the proxemics, the corporal space of the human being and he described it in his book called "The silent Language". There, he talks about the different distance and different postures.

The posture is the most difficult gesture to describe, Albert Scheffler discovered people imitate the corporal attitudes from the others, and they change of posture according to the situation, besides it is the clue to analyze the attitude and character.

The corporal rhythm according to William Condon, says the body human dances continually to the breadth of the speech, because each time someone speaks, the movements of its hands and his fingers, the movements of its head and all body movements coincide with this compass. 


\section{Communicative Approach}

The communicative approach started as a fundamental contribution around the programs elaboration, and towards 70's sets up the communicative competence as the principal objective in the language teaching through the development of linguistic skills.

Its learning vision is based on the experience, where the student is the central point. Also the objectives of this approach are:

1. Communication: the communicative acts are real and propitious for the learning of a second language.

2. Task: Meaningful activities that require the use of the second language.

3. Meaning: it has to be something meaningful for the learner, it facilitates the educative process.

The communicative approach depends of the nocio-functional programs and criteria attached to the contents and functions, and the teacher's figure who motivates and contributes to the process improvement. Also, it goes beyond the sentence limit and use the communicative methods that works the language in a discursive level, taking into account pragmatic and socio-linguistic criterions focus on the communicative aim according to the context.

On the other hand, the communicative approach has its theoretical bases on the micro-linguistic and macro-linguistic, the first one makes reference to the study of the language as a code; and the second one makes part of the social and psychological study of skills, as a source of social interaction. (Cfr. Sawas: 1986,
8). There students develop socio-cultural, discursive, linguistic, operational and strategic competences used in different communicative acts.

In this order of ideas, this proposal is going to take into account the communicative competence model proposed by Dornyei and thurell, and Celca- Murcia (1995). Socio-cultural competence

\section{Discursive competence}

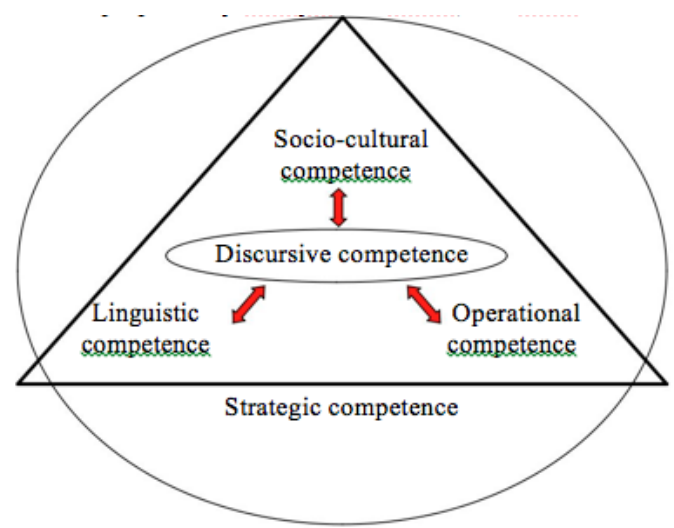

The previous graphic shows the five different competences used in the communicative act, where the linguistic competence makes reference to the syntaxes, morphology, lexical and phonology of the language; while the sociocultural competence is the knowledge and use of polite forms of the language; and the operational competence is the capacity of producing and appreciating a communicative intention through the execution and interpretation of a speech act. These competences help to develop the discursive competence, which makes reference to the discourse that a speaker can produce in a language and facilitate the development of the other competences. And at the end of this graphic, we find the base of the competence's triangle, referred to the strategic competence, a whole of skills used to solve problems or redeem deficiencies in the other competences. (Cfr. Diaz: 2003, 64-65) 
Afterward, these competences improve with the help of the communicative abilities or skills: those are listening, speaking, writing and reading. These skills involve an active vision among them, because if someone wants to speak fluently first has to listen to, and if someone wants to write in a good way first it had to read before. As a result, the communicative approach allows the students to ask information, to express their ideas and their opinions and, they can discover the answers by themselves (Sawas: 1986, 9). Besides, the communicative approach considers the students' needs, teachers determine what kind of situation is going to be presented for creating the communicative atmosphere, and this context has to be common for children. As well, teachers have to keep in mind the student's age, their social context and the previous knowledge of the topic (Cf. Sawas: 1988, 9).

Thus, in this project the teacher selects four videos each one of them based on a different kind of speech, to see an example and then reproduce the same speech with a different topic, because through the videos they can listen and then produce oral performances where they will improve their speaking level.

In order to analyze the oral interaction in intermediate student from the Language Center, this proposal is going to use the ethnographic observation and the recording of videos as sources for recognizing the communicative competence in speaking performance. As a result, the objective of EFL learning will be the uses of verbal and non-verbal communicative strategies to communicate their own point of view and get confidence in their self through the oral interaction based on speeches where they acquire the knowledge to inform, give directions, demonstrate and convince their interlocutors.

\section{Performance Analysis}

Since many years ago, there have been several studies that tried to analyze the differences and similitudes between the mother languages and the target language, and different scientists have made models that represent the phases in the second language process.

Thus, it appears the error analysis at the end of the 60's, inspired in Chomsky's theory which studies the errors made by the learner when he uses a second language with a principle where the mistakes makes part of the learning process and this is the only way to learn, where Pit Corder says:

"If the nature and the quality of the mistakes do not give an exact measure about the second language knowledge, this gives us an important source about the knowledge nature" (1973:254).

And these errors are classified into two groups; the first one influenced by the mother language, and the second one, which has other causes, like the over generalization, hipper correction, meanings expression and simplification. In this sense, the error is learning prove, where the student makes hypothesis about the organization and configuration of elements, and deducing and applying structure rules to the communicative performances.

Then, it comes the performance analysis that studies the student's competence through the global linguistic performance, paying attention to what is able to say and do with the target language not only the errors that makes.

Nowadays, the research is determined by the discourse analysis, which appears as a result of a need of working not only in the student's performance also see proves of the language he receives. 
This model tries to find out the relation between the input (come from the teacher or materials) and the forms and development of his Interlingua and all stimulus he receives and listens, that implies someone to listen to, answer to and someone to communicate with.

Thus, the most important part in the discourse analysis is the conversation analysis that implies a negotiation and meaning construction, where all the communicative strategies used in the oral interaction are analyzed in this kind of model and also takes into account variables as age, aptitude, motivation, attitude, personality and cognitive style to make a deep speech analysis.

\section{Media: Use of video in the classroom}

The technological advances in the recent years have made teachers consider the use of this new technology in their classes, which has been nowadays a fundamental aid in the learning process, and most of the language teachers have started bringing new equipment to the classrooms in order to create innovative teaching and learning strategies.

In this sense, video is one of these technological tools that have been used by most of the English teacher since few years ago, where this audiovisual aid provides a real language example for the students.

As Bouman says about the video use (1986:14) "it presents language being used in all its aspects "grammar, vocabulary, communicative functions, pronunciation and intonation" which means that, the video facilitates the language learner to develop awareness about the English language in use and facilitating the comprehension of native American speakers.

At the same time Bury (1993) says that the characteristics of the video provide socio- linguistics factors that find out which type of register should be used in different social situations, for example it is going to be different the linguistic expressions used in a formal that in an informal conversation.

On the other hand, and attaching the use of video with the speech analysis, for Hick (1982:95), the video "can present discourse features such as the organization of information in a speech with hesitations, pauses, repetition, restatements, among others", where it can demonstrate common behavioral aspects of communication as the appropriateness of reactions among negotiations.

The video scenes can be used as samples to explain different aspects in communicative situations. Goodman (1985: 80) sees the advantage of video in its "capacity to repeat endless and without alteration the same linguistic data: and that students' attention can be directed to different aspects of communication with each view".

On the other hand, there are some limitations we should take into account before introduce this tool in the classroom, like:

1. The face to face interaction is not possible due to the nature of the video produce for a distant audience

2. Some viewers watch videos for relaxation and entertainment and not as a teaching aid.

3. The video could become passive if teacher doesn't have an objective and provide students with an accomplish activity.

Even though the video has some limitations, it also has some advantages that have to be used in an appropriate way because this tool brings to the classroom real speakers 
immerse in a spontaneous speech, which has frequent pauses and overlaps.

Thus, it is important to create new strategies that show students an idealize way to speak in English based on the comprehension and real production that they make themselves.

\section{Research Design}

\section{Type of research}

This project is focus on the descriptive study, according to Guillermo Briones, this kind of studies is focus on the representation of the object studied through the language, explaining different parts, qualities or circumstances.

Thus, the main point of the descriptive research is establishing criteria in order to select the elements that will be the main research exes to systematize the pertinent information and present it. At the same time, the descriptive research has two modalities the quantitative and qualitative, but taking into account the objective of this proposal, this project is going to be based on the qualitative research analyzing in detail following the previous literature review using the ethnographic instruments.

Moreover, the object of study will be the analysis of student's speech construction, exploring in a deep way all their speaking process and characterizing it through verbal descriptions, where I am going to talk about the setting, main features and analysis of the phenomenon observed, using the ethnographic field notes and the selection of variables guide by the theoretical information.

Thus, this research does not find out a solution for a problem, this research explores the nature of the speaking process, knowing where their ideas come from and how they use the language to communicate their ideas.

\section{Project's stages}

As this project is based on the descriptive research (Briones, 1998), it is important follow its investigation's way, for instance, the phases taken into account in this process will be: observing, collecting data and analyzing.

First of all, the observation process will be done by the teacher, where the field notes are the most important tool in this phase, because through them the training teacher will analyze the students' actions and attitudes towards the English learning and oral production.

After the observation, comes the collecting data phase, where the interview will be an extra resource to try to identify personal interests and motivations toward the learning English and the oral skill development. On the other hand, the organization and analysis of the field notes will help in the design of the strategy that is going to be use in the study of the students' oral performance.

At the same time, it is important start constructing the literature review, which will support the conclusions of this project. And while the characterization of the oral skill performance is done, the activities created by the teacher will be the mechanism to do a deep study about how the students communicate in English and all of them will be recorded in video.

Through the information collected in field notes, interviews and videos, it is possible to find some specific categories and subcategories that help to build the data analysis, and from this analysis I can get conclusions and answers, that act in response of the questions proposed by this project.

This project takes place in the Language Center, an eight floor building and a 
branch from the National Pedagogical University, located in Chapinero's locality, in the address Calle 79 \# $16-32$, Heroes neighborhood.

The Language Center is an academic community for the foreign language learning and aimed to different ages and genres, but most of its students are teenagers and adults. This institution has different level programs, and offers weekdays and Saturday schedules, which are available during the whole day, giving the students a big chance to get the most convenient for them.

The mission of this center is to consolidate an academic community who contribute to the social and cultural development of the country through the diffusion and develop of academic programs focus on the knowledge of the foreign languages. The vision is to be able of answering to the education necessities of the country and the formation of the excellent speakers, for this reason the emphasis is done on developing communicational and cultural skills.

On the other hand, this area is known for different technological centers. Around the building, there are many computer enterprises, shopping centers and bank branches, and its main public is adult.

\section{Population}

The conversational group is composed by six students, all in an intermediate B1 level according to an online test applied on august $10^{\text {th }}$ in the web side www.examenglish. com from Cambridge. This exam evaluates and describes the level according to the common European framework reference.

On the other hand, the students' age has a wide range, because there are five students from 16 to 20 years old, and there is another one who is 56 years old. According to the personal interviews, most of the students live kind of far away from the Language center what makes difficult their arrived to class on time. The students are all women, and most of them are students, others are housewives.

Now, taking into account their principal reasons to learn English, they said the principal reason is because they really like the English, and they understand the important meaning in their future carries or travels to other places where the first spoken language is English.

According to the activities done during the free time, most of them prefer watch TV, listen to music and go to the movies. Activities related to the listening and visual features. In the last place, we find the reading, studying and sleeping as the leisure activities more common.

Now, the question related to the improvement of one of the skills, most of them chose speaking and writing, while the other ones choose listening and reading. To work in groups, they like better work in pairs, and the activity the like the most is make conversations and watch videos.

\section{Collect data techniques}

The current project is using two main ways of collecting data in order to have specific information, and obtain a satisfactory analysis of each project's phase. In this sense, the techniques used are:

\section{The field notes}

The field notes are events descriptions, written in a relatively factual and objective style, focus its description on who, what, where, when, how and why questions (Burns, 1994). They might include nonverbal information, physical setting, group structures and conversational expression used in the classroom, and interactions among the other participants. The field 
notes (Porlan, 2000. Pages 39-40) are useful for describing, analyzing and evaluating scholar reality, because on it you can find the register of a continuous process that let the teacher make constructions and hypothesis about this process written on it.

\section{The video recordings and transcriptions}

In this project the video recording is used to recognize the oral skill performance of each student, at the same time the teacher identifies attitudes, influences and main features when the talk in a foreign language, identifying the communicative strategies used by them.

Thus, the video will work as a collecting data technique and as the implementation process, describing the oral performance and analyzing the communicative situations settle to develop the proposal through the creation of four different speeches with a different subject.

Also, the transcriptions of each video will be used to analyze the verbal and non-verbal communication, through the hesitations, the pauses and the repetition of elements along the discourse.

\section{Pedagogical Design}

\section{Description}

First of all, it is necessary to say that the activities that compose this pedagogical design also make part of the data collecting, instruments that support the analysis of the oral performance and structure the implementation.

In this sense, to analyze the oral performance of intermediate level students, this research will work with four different kinds of speeches: the informative, the layout, the demonstrative and the persuasive speech, in order to simulate different situations students have to deal with.
In this order, the project will be based on short presentations that will be recorded on video to see and appreciate the verbal and non-verbal communicative strategies used during the communicative process.

In addition to that, the pedagogical design will work with the task-based learning, where the tasks will be based on a specific type of speech, will follow the order of its characteristics and will point to the purpose of each one of the speeches. In this case, for every task, each student is given a different set of information that has to be presented in different ways, while their partners make part of the information exchange and a fundamental part in the oral presentation through communicative interaction with the speaker.

Thus, there will be brief instructions given by the teacher to know how to do each speech and the rules to do it as the time control and visual aids. Simultaneously, students will have plenty of time to prepare and present their topic through a specific speech, and at the end of each presentation teacher will give a feedback to each student. Here you can see the schema created to follow the process.

\section{Pedagogical Design}

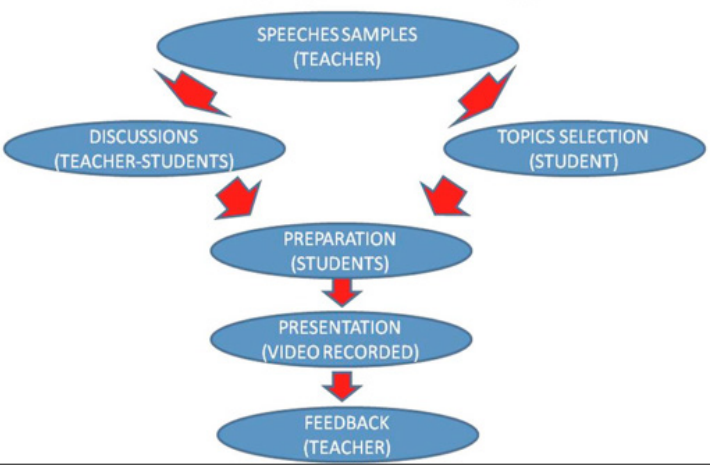

\section{Objectives}

These activities are intended to encourage independent learning and to point the students' difficulties around their oral 
performance and the oral skill improvement.

As general objectives, the activities based on four basic types of speeches are made:

\section{General objective}

- To develop a communicative competence through the management of different kind of discourses in the conversational group of the language Canter.

\section{Specific objective}

- To involve students in an interactive and meaningful space focus on the communicative competence as a social vehicle in the oral interaction.

\section{Methodology}

This proposal is going to be focus on the Task based learning; a pedagogical methodology developed in the 80's and based on the communication and process through tasks. It appears as a renewal option derivate from the communicative approach which became a famous learning method with fundaments as: take of decisions and negotiation, two elements that come from the student.

David Nunan, is one the most important defenders of this research who says this kind of research goes from the particular to the general belongings and defines the task as "one part of the class work that makes students understand, manage, produce and communicate in the target language, focusing their attention on the meaning and not in the form" (1989:10).

In this way a syllabus guide by the taskbased has to take into account next questions: What objectives they want to reach, what contents will have the program, what kind of activities will be use and how it will be evaluated.
At the same time, the task-based has a task schema, and according to Giovanninni (1999), the global task structure is composed by:

1. A final product or a work result. It has to be something observable like a text, a video, a mural, a debate, among others.

2. Materials that proportionate information, stimulus and ideas to complete the task.

3. Topic or ambit: It could be the same product but has different topics depending on the students' interests.

4. Activities: It is the task development.

5. Contents: since the linguistic system, it is all the linguistic elements necessary to complete the task, as vocabulary and intonation.

6. Agents: people who is going to do the task, if it is in couples or individually.

On the other hand, the activities will follow the previous elements and will bedone according to the next order.

1. Teacher gives an example of each kind of speech, this will be on video and the oral interaction will be through questions.

2. Students select a topic for each speech, starting with the informative and then with the others ones.

3. Students prepare the visual aids and other elements to work with. Show to the teacher the ideas and way to do it. 
4. Students present their speech in a creative way and make an activity to interact with their partners.

5. Teacher evaluates the presentation and gives a feedback.

\section{Implementation Activities}

The implementation activities are based on videos, which were used a collecting data technique to analyze how the students construct their speech, their ideas and know where they came from and how they socialize them.

Thus, the activities are going to be based on four different kinds of speech (informative, layout, demonstrative and persuasive), which I selected taking into account their use in the real life and they fix into the model of a learning English process because of their communicative functions. Also I picked them up because they can be organized and presented from the easiest one to the most difficult according to the performance elements and exigent grade.

Thus, the first three speeches are going to be done individually and the last one that makes reference to the persuasive speech will be done in groups of three.

\section{Data Analysis}

In this part, I present the analysis of data gathered from study of oral performance and communicative strategies used by the Conversational group at the Language Center, through the analysis of four different speeches recorded on video.

In this way and in order to reach the objectives and answer the questions proposed in the project, it was fundamental to analyze the field notes, video's recording and transcriptions as well, for finding new interesting aspects around all communicative features handle by the intermediate students. Thus, and taking into account the process developed through the descriptive study, I observed and identified one main category that let me analyze and understand the students' speech construction.

Likewise, the data analysis was divided into two patterns which emerged from the data collecting instruments and implementation activities, where the previous knowledge is presented as main category found it in the research process and facilitate us to regard how the students oral performance is portrayed their speech construction recorded on video through four different kinds of discourses.

In this sense, when analyzing students' oral performance through the implementation of video speech recording and data collecting activities such as the field notes and video transcriptions, it is evident there are some repetitive features along all process, which were analyzed and organized in patterns that give details about useful elements in the oral communication construction.

In this sense, it is relevant to say one of the most common aspects among learners is the relations or associations they establish between the new knowledge and their prior one. In fact, all the time students use their past and social background for understanding the new knowledge they are getting to and facilitate them to interact with other. Thus, the following two spheres: Communicating ideas through personal experiences and Interacting according their personal interest will explain the previous knowledge as the main category found in this research process which characterizes the students' oral speech construction in a foreign language.

Likewise, the main pattern makes reference to the constructions of ideas taking into account their personal experiences and how the use of this kind of examples 
facilitate their oral participation in class; while the second pattern refers about how the personal interests related to their way to life influence their learning process and contribute to the oral skill improvement.

\section{a. Communicating ideas through their social and personal background.}

At this point, the first feature set up in the field notes and video transcription was the communication of ideas considering their social and personal background, which refers to the construction of thoughts taking into consideration their individual or collective experiences live in different moments, because this represents a previous knowledge came from the relationship between student and his context, which gives several meaningful elements to talk about and allows student to construct their own speech in a foreign language based on known elements for them.

In this sense, Ezana Habte affirms "students tend to learn more when they are able to share aspects of their personal life" (Gabr, 2007), and this situation was live out in several English sessions where students used their personal anecdotes to illustrated a knowledge in an oral way.

In the light of this, we can see this situation clearly in next field note quotations and video transcription. In this first example some students told us about their experiences lived in different places in the United States and in the second one, a student tells about how she prepares a recipe in her house:

"When I showed them the pictures, they opened their eyes what made me think they were really exciting to talk about that, so they talked about their experiences, like: Luz Marina had traveled to New York with her son and Alejandra traveled to Florida in a girls trip when she was 15". (See field note \# 1)

"I use regular tomatoes, but the real Caesar salad uses cherry tomatoes, that are the small ones and are really delicious. Also when I prepare this salad, my son loves the vinaigrette and put it a little bit of vinaigrette on the top". (Video transcription)

At the same time, another kind of example is the personal anecdotes to create new sentences relating to the topic seen in the explanation and the oral exercises.

"When they were giving the examples according the topic of the day Such as and So... That. They used sentences like: The class is so exciting that I will learn a lot; my classmates are such a great people; my boyfriend was so boring that I left him, my husband is such a great lover. They laughed a lot in class, because they used personal examples, including relationships and personal anecdotes" (See field note \# 3)

"In this case, we are gonna use next expressions to make .. to fold the paper following the expressions that I said you before. So, we have to take this corner and fold it up and then flap it and do the same with this corner" (video transcription) 
In this way, it is clear students use previous concepts to build complete sentences which carry a specific meaning according to students' experiences. Moreover, when they include personal events in their speeches facilitating their oral performance $\mathrm{d} \mathrm{u}$ e to the fact they know a n d feel comfortable talking about it.

In this point, all aspects which involved personal events are relevant in the foreign language learning due to the supporting process that give this kind of

examples, because students will always want to talk about their family background or cultural references, even about silly personal situations they had have to deal with. For this reason, I can say the use of personal experiences as a topic to create different activities is and will be the most used effective strategy for enhancing learning and oral interaction among students.

Likewise, it is also interesting to see that students feel more comfortable when their teacher allows the oral interaction based on an understanding and friendly class, because they feel free to express their own opinions and ideas without limitations, such as Habte, who says again, that "students tend to establish strong relationship with teachers, who creates a familiar space to speak about their own experiences" (Gabr. 2007).

In the light of this, the next example shows us the previous situation:

"They really did an excellent work, and they expressed they will try to get better through every activity. On the other hand, they seem happy in the classes and they ask me for more exercises. At the same time, they express they feel comfortable when they talk to me, because I'm friendly and understanding according to them, and also because I don't interrupt their speaking, I just let them talk and at the end I give them a feedback and give them the advices to improve their oral performance, which makes me think about their confidence when they communicate their ideas to a familiar person who doesn't criticize their oral participation" (see field note \# 5)

Moreover, the space given by the teacher for interacting in a familiar way is presented here:
"Ok, today I'm going to talk about how to prepare a cocktail, and as we are between friends, I will use just a little bit of alcohol because it is not allowed but anyways we know a cocktail is not a cocktail without it" (video transcription)

Thus, we can appreciate students are not shy when they are in a pleasant space to talk, and they start taking risks in their oral interactions focusing on the meaning and not in the form or grammar structures, which facilitates their oral fluency and oral skill improvement.

In this sense, the oral speech construction developed by the conversational group was characterized for a familiarity context, because I could see they made a strong friendship inside and outside the classroom, even they tried to share their personal interests with their own classmates and all of them were participative and showed a respectful attitudes toward different believes and way to think. 


\section{b. Personal Interests: Cultural symbols used to interact in English}

There is no doubt the non-verbal elements make part of the communication and in this case other kind of non-verbal acts composed the oral speech construction, specifically the use of symbols that express their living style and way to think which is represented through specific topics related to their personal interests.

In this way, those symbols guided their oral performance since they seem more confident when they talk about a topic known by them. Thus, each student based her speeches in something near to their thinking way, as the next quotations affirm it.

"Luz Maria started the class reading God's word, taken from one part of the bible and she did the relation between her demonstrative speech and the Lord's word.

Then, she prepared all her tools and started the Caesar salad preparation. On the other hand, Sandra made her demonstrative speech about how to do figures in origami, she gave us two papers from different colors to start folding and giving a shape to a plain paper" (see field note \# 6)

The same was observed in the next video transcription, where it is evident one of the students is interest in the Japanese cultural elements.

"As you know, I love all Japanese things and "manga" designs, for that reason I decided to show you an interesting practice in Japan known as Origami, where people create different figures folding papers, as we will see today" (Video transcription)

In this sense, we can see that in a conscious way they decided to choose their own topics, related to important elements in their life, because most of their speeches were made based on the same subject, the religion and the Japanese Culture. The first one expressed through their bible quotations, as we can appreciate clearly in next extract, where she said:

"Ok hello my name is Marina
Pinto we are preparating
Caesar

Salad, ehh but first the word bible said at 11:9 I was in the city of Joppa praying and in a France. I saw a vision. I saw something like a large sheet being let down from heaven by it's four corners and it came down to where I was. I looked into it and saw four footed animals of the earth wild beasts, reptiles and birds of the air, then I heard a voice telling me "get up, peter kill and eat; I replied "surely not Lord. Nothing impure or unclean has ever entered my mouth. The voice spoke from heaven a second time "do not call impure that God has made clean". (Video transcription)

The same is described in some field notes, where one of the students always read the God's word to emphasize her beliefs and let us know everything she does has to be related to Jesus:

"Luz Maria started the class reading God's word, taken from one part of the bible and she did the relation between 
her demonstrative speech and the Lord's word." (See field note \# 6)

This is observed inmost of the performances, where the personal experiences and thoughts related to a specific ideology or point of view were always present in their speeches, which can be interpreted as a sign of an internal process where students use the target language to communicate their own ideas to others as they do in their native language in order to interact based on social and common subjects.

In this sense, we can identify a common characteristic in the conversational group, where students mixed their beliefs through their own speech practice, doing the same along all the process picking up a topic related to their interests and more comfortable to deal with. Thus, the previous knowledge of students has a fundamental role in their learning process because students recognize subjects and topics that come from their own interest which make them feel identified with it and facilitates their oral performance as well.

In the light of this, it is important to conclude saying students tend to consider their background knowledge in different ways, from their grammar knowledge to the organization of information taken from their cultural dimensions, which show a general comprehension about their reality and allows the interaction as an active process of learning where students create new forms to participate and share their beliefs in an oral way.

\section{Conclusions}

The process developed with the conversational group of the Language Center through the data collecting techniques and implementation of video recording following a task-based approach, had as a result the analysis of the most remarkable aspects found in the field notes and video reproduction. In this sense, the categories established as main patterns and the interactions observed in all English sessions, allow me to explain how students construct their own speeches in an oral way, where the personal background and main interests related to cultural dimensions are the most important findings in this research process.

Thus, the patterns analyzed beforehand make reference to the previous knowledge and personal interests as main factors that provide a mental resource to interact in English, but through this analysis I can say that students construct their own conceptions about their own realities and took them as interesting topics to talk about in class, facilitating them to interact and make other interpretations about it in a second language. Moreover, these personal constructions emerge from the interaction between the individuals and their context, where the individual who interprets his reality is the same one who reconstructs their speech based on his previous knowledge and tries to communicate it in a second language, based on their own cognitive and social knowledge construction which enriches their oral skill improvement.

Thus, these personal constructions are based on an experiential exercise, where the student and his previous knowledge are the main parts of the process, having a specific type of representation according to their realities and cultural dimensions which is presented from different ways through their oral skill performance. In this sense, what I had exposed until here is supported by Rodriguez Maria (1999), who says people have a declarative and a practical knowledge, where the first one makes reference to the concept's description; while the second one corresponds to the application of that declarative knowledge. Thus, if student has a huge variety of declarative knowledge, it will be easier 
but at the same time more complex the production and organization of them in an oral way.

In the light of this, it is possible to affirm the previous knowledge is a representation that emerges from all communicative actions done by students because the declarative knowledge and the practical one can be seen through all their interactions, since they selected their own topics, they have a strong concepts' appropriation and show confidence when they talk about something known for them and makes part of their beliefs and cultural interests as well.

In this sense, learners established different meaningful constructions through the activities based on the reproduction and recording of different discourses, process that let us understand that the previous conceptions, own interests and cultural topics are the most important resources in the oral interaction where teacher supports their speaking process taking into account their needs and points of view.

\section{Implications For Further Research}

According to the previous considerations and all process developed along this semester with conversational group from the Language center, this proposal was helpful due to the fact the oral skill performance has not been studied a lot from a pragmatically way because most of the found studies showed the oral skill under a linguistic conception. Thus, this kind of research is necessary in a foreign language learning process, because teachers can use next statements to analyze other teaching methodologies based on how students' learn a second language.

In this way, they can focus their pedagogical practice on communicative teaching methods, stopping a grammar education in the foreign language education and learning process. Thus, the activities proposed in this research considerate the communicative approaches, where the most important element is the development of communication related to the contact with others based on meaningful interactions that allows the construction of new knowledge.

At the same time, this proposal supported the process developed in the last level offered by the Language Center as a result of work done with the students, because from the video recording presentation and manage of different speeches was developed the final project, where each student had the opportunity to choose once again a topic and a kind of discourse, which had to be prepared and presented in front of the Language Center community members. Thus, this process showed the students' oral improvement, because they were able to construct a real communicative skill immerse in a process based on tasks where the final product was the final oral performance counting with other spectators from the same institution, where students showed a spontaneous oral performance taking into account an earlier organization.

On the other hand, this study could be considered as a starting point to go beyond a descriptive research and set up an explicative one, generating new teaching options through the creation of new and more complex communicative situations to keep analyzing the previous knowledge under a deeper cultural dimension. In this sense the oral skill analysis from a cultural aspect could be an innovative study field, where would be interesting start a research process taking into account the effects caused by the cultural changes in the learning student environment and educative process. Thus, the contact between different cultures and new social ideologies could involve unknown aspects in the development of the oral skill and the communicative competence in general 
where it would be necessary start a new research process.

\section{Bibliography}

Birdwhistell, Ray L. Kinesics and context. Philadelphia University of Pennsylvania. Press. 1970

Briones, Guillermo. Métodos y técnicas avanzadas de investigación aplicadas a la educación y a las ciencias sociales. Segunda Edición. Bogotá. 1998.

Bruke, Peter. The art of conversation

Davis, Flora: La comunicación no verbal. Alianza editorial. Madrid. 1986.

Efron, David. Gesture and environment. La Haya. Mouton. 1071.

Erlbawn, Laurence. Progress in the psychology of the language. Associate. 1985

Goodman, K. Whole language: what makes it whole? In literacy in process, R and Miller. New York. Longman. 1991.

The repertoire of non-verbal behavior: Categories, origins, usage and coding, en semiotic Vol 1, page 48-98. 1996.

Labarre, Weston. Comentario sobre "proxemics", por Edwar J Hall, en current Antropology. Vol 9. Page 101-102.

Littlewood, William. La enseñanza de la comunicación oral. Un marco metodológico. ISBN: 8475099858.

Mallas Casas, Santiago. Didáctica del video. Barcelona. Ed. Alta Fulla. 1987.

Pastor Cesteros, Susana. Aprendizaje de segundas lenguas. Lingüística aplicada a la enseñanza de idiomas. ISBN: 84-7908803-6, pág. 97-125.
Rodriguez Mono, María, conocimiento previo y cambio conceptual. Ed. Aique. 1999.

Sawas Odapas, Diana. Desarrollo de las cuatro habilidades necesarias para la adquisición del Ingles bajo el enfoque comunicativo. Bogotá. Pontificia Universidad Javeriana. 1986.

\section{Articles References}

Gabr Habte, Ezana. Socio-affective strategies in teaching English language content in Bogota. Educating with Pearson Longman. April 24th, 2007 